\title{
Tanning My Hide With Research
}

\section{Robert E. Young}

My intellectual work has important consequences for me and for those with whom I ply my trade of faculty development. The time seems right to stop and discern those consequences, not because I have great wisdom to share but because such an exercise provides a glimpse of one mortal trying to integrate intellectual work into day-to-day professional life.

The title of this paper suggests a double metaphor and a theme which emerges when I think about my intellectual work. I recently returned to the Upper Midwest of my upbringing, and the ways and the words of a strict and agrarian people. The "tanning of hides" in this experience means two quite different, yet salient, things. First, it means the turning of a raw product into a functional and even elegant material. A cowhide is not useless in its untanned form, but with refinement it uses multiply and its value increases. It has worked the same way for me as a faculty developer. The values, knowledge, and skills I bring to my work have use, just like that cowhide. But my intellectual activities - my research and my writing - give a suppleness and attractiveness which I believe enhances my value. I may not be like fine leather, but I can now cover deeper contours on the body Academe. I find I'm more resilient in the bad weather that is sometimes our work, and I certainly must smell better to some colleagues than if I did not have some sort of intellectual work underway.

The other meaning of my title suggests a second reality in my intellectual work, although it raises less positive memories of my 
childhood. When I disobeyed my mother or father or when I got into some unforgivable mischief, my father would "tan my hide." That is the way he would put it. As a psychologist I eventually came to call this an aversive stimulus, but then it was simply a sore fanny and usually a lot of tears. Well, research and writing have had these consequences also, and I describe some of the negative effects in greater detail below. My intellectual work - and the ways I have gone about it as a faculty developer - have caused me and others embarrassment, worked against other development activities, and even caused me physical pain and tears of sadness.

Now let me be more specific by commenting on topics common to all authors of these papers.

\section{Some Central Intellectual Issues}

One overarching issue has predominated: the thinking and behavior of college teachers, as these wholly human activities affect what one does in teaching. I am interested in students, methods, materials, teacher-student interaction, and institutions as they influence the teacher and as the teacher influences them.

How did I arrive at this focus for my research and writing? First, I should say that I have not been at it very long; the sharpening and elaborating process has not had much of a chance to do its good. But I can identify an intellectual legacy and sketch a pathway to my present interests and perspectives.

My academic preparation accounts for much of my view of the world. And most important in that preparation as an educational psychologist, I believe, was the luck of growing up intellectually and professionally in a milieu of varied and often competing theoretical positions and empirical interests. I am speaking of my academic department, one small wing of a building where offices all face out into a room that became a melting pot of academic and personal interactions. Don't get me wrong; some of these people never spoke to each other, but their ideas found ways of seeping under even the most tightly closed doors. And for those of us who spent much of our lives in the room, the effect was undeniable. 
My advisor was a behaviorist, but a very special kind, one who allowed that other things besides contingencies of reinforcement affect behavior. Next door to him was a person committed to the idea that social structures - classrooms, schools, educational systems have a predominant effect on thought and behavior. Then on the other side of the entryway camped a leading humanistic writer! He was a true believer in the importance of emotion and self-esteem for learning and teaching. Finally, dead across the room, over a couple of secretaries' desks and behind a four-drawer file cabinet, was the office of the smartest person I will ever know. He, in addition to providing a daily dose of awe, gave us an up-to-the-minute, play-by-play account of the cognitive movement in the social sciences, psychology, and education.

I have gone on at some length about these people and their setting, but I do not think I overstate this influence on my intellectual work, and, in particular, the issues I find most important. My education in this way provided the foundation for what would happen in my intellectual outlook.

Near the end of my graduate training I was confronted with an idea which has very much taken hold of me and my intellectual work. That idea goes something like this: to understand human behavior, you have to use all the perspectives I had learned about on the third floor of Erickson Hall - and more. You have to integrate them into your soul, as well as into your experiments, if you are to have an understanding that would be worthwhile. Even more strongly stated - and this phrase buzzes in my head - to truly understand something like the thinking or behaving of a human being you have to look at everything and all at once. The behaviorist, cognitivist, humanist, or the other "ists" look at only part of what is going on and look only at certain times. The point is that all are necessary but none is sufficient. I had to find a way to use each, at the same time, in my work. Or so it seemed.

At just about that time another propitious thing happened. The emphasis among educational psychologists - at least the AERA variety - swung significantly away from research on learning and toward research on teaching and teachers. Two pieces of this movement added to my intellectual journey. First, the National Institute of Education conducted a National Conference on Studies in Teaching, 
which consisted of a number of study panels intended to identify the domain of issues in the study of teaching. The composition of the panels acknowledged right off that this research held a variety of different perspectives, theories, and methods; separate panels dealt with Teaching as Human Interaction, Teaching as Behavior Analysis, Teaching as Skilled Performance, Teaching as a Linguistic Process in a Cultural Setting, Teaching as Clinical Information Processing. This reinforced my graduate school experience. But now I was looking for linkages, a way of using different perspectives simultaneously and as luck would have it again, I found just such a way. In the work of one of the panels, the last one (National Conference on Studies in Teaching, 1975) a model popped out that gave me a crude way of thinking about teaching and the thought and behavior of teachers in a somewhat complete and unified fashion - a fashion which the activity under study deserved. The chair person of the panel would eventually go on and found an institute for the study of teaching based largely on this way of viewing teaching. And my following of the institute's activities would become an important impetus to my intellectual work. It probably did not hurt, also, that his person was that very same professor behind the four-drawer filing cabinet.

Just one final event needs to be mentioned for the yellow brick road to my intellectual interests in faculty development to become complete (at least until the new four-lane section to North Dakota is begun). With a degree, an idea, a model - and a new suit of clothes -I took off to my place in Academe. But as soon as I arrived I found I could no longer just learn myself, I had to help others do the same. Specifically, I had to teach people about human thinking and behavior (in educational psychology courses). Courses like that cover a vast array of material, from theories of human development to pointers for classroom tests. The task of pulling together that material in a way that students might find meaningful quite frankly stumped me. But once more I lucked out. I chose a textbook, authored by an eminent educational psychologist (Cronbach, 1977), in which he picked up on that same idea I had found a year or so before: thinking and behavior must be considered in an integrated way. He even presented a model which depicted learning in a way analogous to the new way of viewing 
teaching behavior. Now I was excited; in fact I was so inspired that I adapted a model of my own, and I built my courses around it.

And, as it would turn out, my research and writing about college teachers in turn has found this way of thinking about human thought an behavior at its core. It only required one more twist, which cause, like the others, unexpectedly. I asked my students on a final exam to use my model to explain one episode of learning. I expected that each class member would choose a student whose learning they had observed. All did just that but one student. She used my model to illustrate her own thinking and behavior as a teacher. I was astounded, first by the independence of this student, but then by the substance of her paper. I had a model of my own to pursue the thing about which I was most interested - teaching and teacher. And, in this model I had a way of thinking about learning and teaching that was continuous. These things had occurred to me before, but my student's act jarred me past my reservations. Also, I now had someone - she was a graduate student - to talk with about my interests and the approach that had come, by the route I've just described, to make so much sense to me.

\section{Some Specific Research Questions}

It should be remembered that at the time my intellectual work began in some earnest I was already working full time in faculty development, particularly in trying to help people provide effective instruction. And I was taking a particular approach to that task, an approach which I called "course planning." In this approach I was influenced by the paradigms of instructional psychology and instructional technology, i.e., the importance of specifying objectives, methods, and testing in some sequential and systematic way. The approach worked pretty well; most people seemed happy, and courses and even student achievement began to change for the better.

But then I started paying attention to some of the "noise" in my system. For example, not everyone produced the same type of objectives, some people ignored advice about proper strategies, other instructors had a hard time seeing a relationship between testing and instructional intent. Also, I began to notice some challenges to the very 
assumptions and theories behind the approach. It was one of these challenges in particular, by a professor of English, that pushed me along in my intellectual work. I decided right then that I wanted to do some research and writing. I decided I wanted to ask "What affects faculty members' thinking and behavior in the context of their teaching? Why do they do what they do?" The questions were quite general, but they were a place to start. And they motivated me so much because they had grown out of my faculty development work, and I saw prospects that answers would pay off for me in that work.

I had some background for the intellectual work I wanted to pursue. At the point of my doctoral dissertation, I was beginning to get involved in the faculty/instructional development business, and I was concerned about the motivation of faculty members to get involved in instructional improvement activities (so were a lot of other people at that time). I asked "What factors would contribute to a university faculty member's decision to participate in instructional improvement activities?" And I did a study which was broadly based in its intellectual outlook; it reflected some of the influence I described above. But it lacked an overriding concept of human behavior and thought to guide it.

So with the intellectual seasoning I have described, and the day-to-day experience to build from and to look forward to enhancing with my research, I set off. First I wanted to do a review of the field, to update and improve the thinking I did in my thesis. It was at that point that I first used in my study of teaching the model of human thinking and behavior which I had developed for myself. I used it to organize the existing theory and research which related to my questions of faculty thought and behavior in teaching, and to identify areas and more specific questions for empirical research. The result was a paper titled "What Do We Know About Faculty?" published in the POD Quarterly (Young, 1979).

At about the same time, I began to be impressed by the issue of context in human thinking and behavior. There was underway a general movement in social science emphasizing the influence of the situation in which phenomena, such as language, took place. Anthropologists led the way, with cognitive psychologists right behind. A paper titled "The Psychology of School Subjects" (Shulman, 1974) 
influenced me greatly. It occurred to me that maybe I should focus my look at teachers' thinking and behavior in a particular context, such as one discipline. Two of the people who had challenged me the most, as I made my decision to do some research, were teachers of English composition. So after some discussion, which I'll describe below, I decided to focus on one subject taught at one level: the teaching of freshman-level writing. Thus my research questions were shaped further.

This decision, in addition to narrowing the focus of the research, had another consequence. It created a collaborative project. The intellectual work, at least around the questions about the teaching of freshman composition, no longer was just mine. Now two professors of English, an educational researcher committed to a contextual approach, a cognitive anthropologist, and my graduate students all coalesced around the project. And, this in turn further influenced the nature of the questions we would pursue.

As the leader, my interest in thinking and behaving in the context of teaching served as a focal point. But two things happened. First, members of this new research group had their own special interests. For example, one English professor was primarily concerned with the question "How do you change the thinking and behavior of composition teachers?" She wanted an immediate and direct application to faculty development. The anthropologist, on the other hand, was most interested in classroom interaction and effect on students.

The other thing that was at work to shape our research questions was a desire to move quickly toward empirical work. Each of us, but the four professors particularly, felt some pressure to turn this interest and activity into some publishable results. So without much discussion we moved ahead at my suggestion to do a study which focused on a certain aspect of teacher thinking: The conceptions which teachers of composition hold about what they do in their teaching.

\section{Research Methods}

Ethnographic methods have loosely guided this investigation of teachers' conceptions of composition. (I will limit myself to talking about just that study in the rest of this paper.) I began with a methodo- 
logical premise, or I should say one evolved as I conceptualized the research I wanted to undertake and began to interact with my collaborators. The premise suggested that looking more deeply into a few cases is more productive than studying many cases superficially. Due to many of the influences already described I have come to believe that to understand something very well, like college teaching or college teachers, you must study it in all its complexity. The only way to identify all relevant variables and observe their interrelationships is to study a few cases over a long period of time, in depth, and from a number of different perspectives. The emphasis should be on validity, not reliability, at least in the stage we find ourselves in the study of college teachers. So the procedures that would govern our research into teachers' thought and behavior, and particular teachers' conceptions, would first gather insights from a few cases and then test them with progressively larger and more diverse samples.

In addition to this premise, three other things influenced our choice of methodology. First, research on composition was becoming more quantitative in its orientation. So we thought more qualitative methods would help us achieve some distinctiveness in this field of research. Also we believed, quite nobly, that we might be able to check what our English professors saw as an overquantification of the inquiry into composition.

Secondly, qualitative methods fit the epistemological values and training of the group better than did more experimental methods. My own background, in addition to educational psychology, rested in philosophy and sociology. And as I have mentioned, both the educational research professor and the anthropologist were committed to qualitative and descriptive methods. And the English professors, with training in literary criticism, found interviewing, observing, content analysis, and other more qualitative approaches more to their liking.

Finally, we figured out quite early that these methods would allow us a "two birds with one stone" approach in our research. I, and one of the English professors, had a hope that we could find a way to do research that had direct faculty development payoffs. Interviewing and observing, we surmised, might fulfill that hope. And, as I will describe below, we were very right. 
So in our first study, interviewing became our primary data-gathering tool and the logical analysis of interview content became our way of determining results. Both the methods we used and the results of this first study are reported in 'Teachers' Conceptions of Composition," a paper yet unpublished.

\section{Negotiating with Participants}

Once I decided to study composition, I knew I had to touch base with those people who had some stake in a study of composition at my institution: the Dean of Arts \& Sciences, the English Chairman, the Director of Composition, and certain senior faculty members in the English Department. They would make it possible or not for subjects to work with me. They could simply prevent me from doing the interviews we had planned, or they could make it difficult for those who would cooperate. Since the two English-professor members of my research team were junior members of their department, their realistic participation depended on the good will of the department toward the project. I did the base-touching, and found that the teaching of composition was a sensitive subject. All agreed to the project, though under the condition that I check regularly with the composition director.

This research, and our approach, became touchy for another reason. We were in effect moving in on the department's research territory. Although not much was going on in research in this area, the composition director in particular felt this was an area of his expertise and interest. That made it difficult at times for me as an outsider and for his junior colleagues whose work on this project threatened to surpass his own.

My strategy was two-fold. First, I asked respected senior members of the department to be the subjects of the study, including the composition director. Secondly, I joined the department's composition committee and provided them assistance in a variety of projects over two years. This act was crucial in my opinion; it demonstrated a more than superficial interest in the teaching of composition and a longer and broader commitment than just one study. 
Rewards to participants were equally complicated. As repayment, I offered my subjects a workable arrangement for the interviews and feedback not only at the end but after each interview. I also offered, only half-facetiously, to make them famous through the publication of interview material. Each of these had incentive value for the various subjects; together they garnered sufficient motivation to start and continue the study. In fact (and we know a reinforcer is something that in fact reinforces) the sessions were stimulating both to subjects and interviewer, feedback was judged useful, and fame was felt in a tiny way by the person to whom we referred in our papers at three national conferences as Professor G.

In summary, I could say that the strategies that paid off most were developing good personal relationships and showing involvement of the researchers in the daily concerns of the subjects, in this case the teaching of freshman composition.

Two failures in providing reward should be mentioned. First, we gave insufficient feedback. Here we did not deliver all that we had promised; a grave error in any endeavor. The press of other activities (the bane of doing satisfactory intellectual work while in a professional position) caused us not to analyze the interview and give feedback to all our participants. We shared with them bits and pieces and all of our papers. But the assistance that we had promised - and our opportunity to use this research as faculty development in itself - fell short. Second, there were negative payoffs in the visibility of our participants among their departments' colleagues. Visibility outside of the English Department worked well. Our interviewees were pleased for us to use them (appropriately pseudonymed) as examples at national meetings and in my own work on campus with faculty members from other departments. But with the department our papers and a colloquia built around our data and analyses provided too much exposure, given a certain competitiveness and contentiousness among the members.

\section{Standards of Quality}

I am afraid always that my standards are not very high, or at least that they are overly pragmatic. I am concerned about reliability and validity of data, soundness of deductions and inferences, and clarity 
of results. On the first two issues I do not always measure up the way I want. Here is where time and expertise for intellectual work pay off. On the last issue, I do much better. Let me say a few words about all these issues.

Two biases allow me to live with compromise. First, I believe that all data are useful, if only for their value in giving us "hunches" about the nature of the phenomenon we happen to be studying. I feel that our present knowledge of teachers is limited, so even limited data and analysis can be useful if cautiously and judiciously used. Second, I believe that practitioners, who are usually not highly trained in research, have something important to contribute. So, the research of practitioners, despite technical limitations, should have a value and a place in any realm of inquiry.

On the clarity of results and the use of results, I have less justification for compromise. This aspect of intellectual work is the most important for someone involved in faculty development. We are in the business of stimulating change, and the results of our intellectual work can be among our most important tools in that business. So not only must papers be well written, but also their placement, presentation, and use must be carefully planned. Also, other ways of reporting results need to be used. In our composition project, we have produced three papers, organized several colloquia, peddled results informally, and used data and analysis in consultations with participants.

A final standards issue has to do directly with publication. As I have mentioned, our work has been presented at a variety of national meetings, but it has not yet found its way into publication. Frankly by standards of most journals, it is not ready, and time is limited to do additional research, analysis, and writing to get it into that form. We have been satisfied to a point with our audience and impacts, especially on our own campus. But we all feel the need to have more influence and to get into print.

\section{Wider Influence}

I try to build that influence into the design and overall strategy of my research. I try not to set my target for influence too broadly. And, I try to involve other researchers and practitioners as early as possible 
in the intellectual work which I have underway. Because context seems so important and because ownership has a lot to do with eventual acceptance, I set my sights on influencing smaller rather than larger groups. In the case of our composition research we hoped first to influence the subjects of our interviews, then others who taught composition in their department, and only in some more general way audiences beyond our institution. We did present papers at national conferences, and we did hope to influence practitioners and researchers at these meetings but our expectations were not very high.

The collaborative approach we used also had an effect on our group members, in terms of their own intellectual outlooks, their interests in research, and their morale as researchers - and, in the case of our English professors, as teachers of composition.

\section{Getting Everything Done}

I should say right off that I do not do a very good job of getting everything done. A good example is the most immediate one: this paper. I prepared the first draft well past my deadline and only in the cracks of my day of administering an instructional development program.

This situation poses a real dilemma, one that is felt deeply and more and more constantly. I need to do intellectual work, in fact I have three needs. First, active inquiry provides me with information important to me in my job. Second, research, and writing play an essential part in my career goals. And finally, I find that I am not either intellectually or personally satisfied unless I have some intellectual work going on - even minimally at all times. But alas, there simply is not enough time to do it as well as I would like to do it.

My satisfaction rests, though, with the sense that the intellectual work I do complete has an effect on my practice and that my practice has an effect on my intellectual work. And that is what I'm really interested in doing: keeping myself a whole and well-integrated person, my hide well tanned. As a professional educator, a faculty developer to be specific, I must be both a person of action and a person of reflection. 


\section{References}

Cronbach, L.J. Educational psychology. New York: Harcourt, Brace, and Jovanovich, 1977.

National Conference on Studies in Teaching. Teaching as Clinical Informational Processing. Washington, DC: National Institute of Education, February, 1975.

Shulman, L.S. The psychology of school subjects: A premature obituary? Journal of Research and Science Teaching, 1974, 11, 319-339.

Young, R.E. What do we know about faculty? POD Quarterly: The Journal of the Professional and Organizational Development Network in Higher Education, 1979, 1, 145-173. 